\title{
Keberhasilan UNDP melalui Program HPMP dalam Pembentukan Kebijakan Perlindungan Lapisan Ozon di Indonesia
}

\author{
Meidiana Farhani \\ Novita Putri Rudiany \\ Universitas Pertamina
}

\begin{abstract}
This article analyzes the role of the United Nations Development Program (UNDP) through the Hydrochlorofluorocarbons Phase-Out Management Plan (HPMP) Program which encourage Indonesia to implement regulations at the ministerial level that aim to undertake ozone layer protection and the phasing-out of the substances that deplete the ozone layer in Indonesia. This shows the role of international organization to shape national regulation in member states. In analyzing these problems, researchers used the framework of the international norm diffusion, specifically the conditions on economic assistance and the interaction with transnational actors, also the State Socialization. This study uses qualitative methods that emphasize non-numeric data and by conducting studies in previous studies. The conclusion of this research is that the UNDP through the HPMP Program has played a role in establishing national regulations related to Ozone Layer Protection and the phasing out of the substances that deplete the ozone layer which is regulated in Minister of Industry Regulation Number: 41/M-Ind/Per/5/2014 and Regulation of the Minister of Trade Number: 55/M-Dag/Per/ 9/2014.
\end{abstract}

Keywords: UNDP, HPMP, Ozone Layer Protection, Regulation, Indonesia

\begin{abstract}
Abstrak
Artikel ini menganalisis peran United Nations Development Programme (UNDP) melalui Program Hydrochlorofluorocarbons Phase-Out Management Plan (HPMP) dapat mendorong Indonesia untuk menerbitkan regulasi di tingkat kementerian yang bertujuan untuk melakukan perlindungan lapisan ozon (PLO) dan penghapusan bertahap terhadap Bahan Perusan Ozon di Indonesia. Hal ini menunjukkan adanya peran dari organisasi internasional untuk membentuk regulasi nasional di negara anggota. Dalam menganalisis permasalahan tersebut, peneliti menggunakan kerangka pemikiran mekanisme difusi norma internasional khususnya mekanisme interaksi dan mekanisme bantuan ekonomi, serta proses sosialisasi negara. Penelitian ini menggunakan metode kualitatif yang menekankan pada data-data non-numerik dan dengan melakukan kajian pada penelitian-penelitan sebelumnya. Kesimpulan penelitian ini adalah UNDP melalui Program HPMP telah berperan dalam penetapan regulasi nasional terkait perlindungan lapisan ozon (PLO) dan penghapusan bertahap terhadap Bahan Perusan Ozon di Indonesia yang kemudian diatur dalam Peraturan Menteri Perindustrian Nomor: 41/M-Ind/Per/5/2014 dan Peraturan Menteri Perdagangan Nomor: 55/M-Dag/Per/9/2014.
\end{abstract}

Kata-kata kunci: UNDP, HPMP, Perlindungan Lapisan Ozon, Regulasi, Indonesia 


\section{Pendahuluan}

Pada 1 Juni 2012, UNDP memulai Program HPMP di Indonesia yang bekerja sama dengan Kementerian Lingkungan Hidup dan Kehutanan (KLHK) sebagai penanggung jawab utama program. Program HPMP diterapkan di Indonesia hingga 31 Desember 2018 dengan tujuan utama penerapan program adalah untuk mengurangi 80,4 ODP ton dalam konsumsi Hydrochlorofluorocarbons (HCFC) nasional di tahun 2018 dan menghasilkan pengurangan emisi langsung setara Karbon dioksida (CO2) neto sekitar 1.5 juta ton pertahun dari tahun 2015 (UNDP, 2017). Pengendalian HCFC di Indonesia melalui Program HPMP akan berfokus pada penghapusan HCFC-22 di sektor servis dan penghapusan HCFC-123 dalam aplikasi pemadaman kebakaran (UNDP, n.d.).

Penerapan program HPMP di Indonesia merupakan tindak lanjut dari komitmen global Indonesia yang telah meratifikasi Vienna Convention for the Protection of the Ozone Layer dan the Montreal Protocol on Substances that Deplete the Ozone Layer berikut dengan hasil amandemennya (UNDP, 2017). Kedua perjanjian tersebut merupakan perjanjian internasional untuk melindungi lapisan ozon yang ditandatangani oleh seluruh anggota UN di bawah kerangka United Nations Environment Programme (UNEP) dan diratifikasi oleh Indonesia pada 26 Juni 1992. Dengan Vienna Convention for the Protection of the Ozone Layer disahkan dalam Keputusan Presiden (Keppres) Nomor 23 Tahun 1992 dan the Montreal Protocol on Substances that Deplete the Ozone Layer serta amandemen pertamanya yaitu London Amendment disahkan dalam Keputusan Presiden (Keppres) Nomor 92 tahun 1998. Keppres Nomor 23 Tahun 1992 memuat dua pasal yang menyatakan bahwa Indonesia mengesahkan Vienna Convention for the Protection of the Ozone Layer yaitu perjanjian internasional untuk negara-negara saling bekerja sama menjaga lapisan ozon. Sedangkan, Keppres Nomor 92 tahun 1998 memuat tiga pasal yang menyatakan bahwa Indonesia mengesahkan the Montreal Protocol on Substances that Deplete the Ozone Layer termasuk ke dalamnya London Amendment yang merupakan hasil amandemen dan penyesuaian dari pertemuan ke-2 para pihak menyepakati the Montreal Protocol.

Melalui penerapan program HPMP, UNDP berhasil memasukan agendanya ke Indonesia sebagai negara berdaulat menjadi regulasi nasional di tingkat kementerian yang bertujuan untuk menghentikan kerusakan lapisan ozon akibat senyawa-senyawa buatan manusia. Kedua regulasi nasional tersebut dikeluarkan oleh dua kementerian yang berbeda, dengan regulasi sebagai berikut: (1) Peraturan Menteri Perindustrian Nomor: 41/M-Ind/Per/5/2014 tentang Larangan Penggunaan HCFC di Bidang Perindustrian; dan (2) Peraturan Menteri Perdagangan Nomor: 55/M-Dag/ Per/9/2014 tentang Impor Barang Berbasis Pendingin (KLHK, 2014). 
Kedua Peraturan Menteri (Permen) tersebut dibentuk untuk tercapainya tujuan program HPMP yaitu mengendalikan persebaran HCFC di dunia, khususnya Indonesia. Dikeluarkan pada tahun kedua penerapan Program HPMP di Indonesia yaitu 2014, kedua regulasi tersebut mulai diterapkan di Indonesia per-1 Januari 2015.

Berdasarkan latar belakang tersebut, artikel ini bertujuan untuk menganalisis bagaimana organisasi internasional menjalankan perannya dalam membantu pembentukan regulasi nasional di negara anggota, sehingga kesepakatan di level internasional dapat diimplementasikan dengan baik. Fokus utama dalam artikel ini adalah United Nations Development Program (UNDP) sebagai organisasi internasional dan Indonesia sebagai salah satu negara anggota Perserikatan Bangsa-Bangsa (PBB). Dalam tulisan ini, isu yang diangkat adalah perubahan iklim yang secara spesifik menyasar aspek lapisan ozon. Asumsi awal pembahasan adalah bahwa keberhasilan UNDP dalam mendorong pembuatan kebijakan PLO di Indonesia disebabkan oleh adanya interaksi kedua aktor yang intensif sekaligus dorongan secara finansial yang juga didukung oleh proses internalisasi yang kuat dalam mengimplementasikan program.

Diskusi tentang UNDP telah banyak dilakukan oleh peneliti dari berbagai kalangan. Filkin, et al., (2010) menyatakan bahwa program Hydrofluorocarbons (HCFC) Phase-Out menjadi salah stau program dari agenda SDGs yang diterapkan di bawah kerangka program UNDP di negara-negara di dunia, terutama negara-negara berkembang dengan tujuan program adalah mengendalikan persebaran HCFC. Keterlibatan UNDP pada aktor negara untuk mencapai perlindungan terhadap yang disebut global public good dan berusaha untuk menyelesaikan permasalahan terkait isu global yang tidak dapat diselesaikan secara unilateral termasuk ke dalam usaha aktivitas pemerintahan lingkungan global.

Program HCFC Phase-Out telah diterapkan di berbagai negara, misalnya di Indonesia pada tahun 2012 hingga 2018 dan di Bulgaria pada 2010-2015. Pada penerapan program HCFC Phase-Out, Bulgaria dirasakan dapat berfungsi sebagai contoh bagaimana suatu negara yang maju dengan baik dalam transisi menuju ekonomi pasar dapat tunduk pada kewajiban program HCFC Phase-Out yang lebih ketat sehingga proyek di Bulgaria dapat menjadi pelajaran bermanfaat bagi negara-negara yang juga terlibat dalam proyek ini (Filkin, et al., 2010). Pada penerapannya di Bulgaria HCFC Phase-Out bekerja sama dengan the Ministry of Environment and Water of the Republic of Bulgaria (MOEW), mempekerjakan para ahli lokal yang dikontrak oleh UNDP dengan asosiasi MOEW dan konsultan internasional UNDP (Filkin, et al., 2010). Hal ini dilakukan untuk merencanakan dan mengimplementasikan inisiatif untuk meningkatkan efektivitas program manajemen ODS saat ini, khususnya terkait dengan memastikan 
penyelesaian HCFC Phase-Out pada tahun 2015 sebagaimana yang telah tertera dalam persyaratan Uni Eropa (Filkin, et al., 2010).

Sebelum penerapan HCFC Phase-Out, Bulgaria telah memiliki regulasi untuk mengurangi emisi $\mathrm{HCFC}$, menjaga lapisan ozon dan menjaga kebersihan udara sebagai global public good (Filkin, et al., 2010). Hal ini menunjukkan Bulgaria sebagai sebuah negara telah memiliki regulasi domestik yang sejalan dengan tujuan Program HCFC Phase-Out untuk mengendalikan HCFC. Pada penerapannya, UNDP melibatkan pihakpihak yang dapat dikategorikan sebagai masyarakat lokal yang terwakili oleh agensi-agensi seperti Bulgarian Drug Agency, National Customs Agency, Bulgarian Chamber of Machine Building, Chamber of Engineers in Investment Design (Filkin, et. al., 2010). Program ini membuat sejumlah rekomendasi spesifik tentang strategi dan rencana aksi yang berlaku pada periode 2012-2015, antara lain (Filkin, et al., 2010): (1) meningkatkan kesadaran; (2) memperkuat penegakan dengan menerapkan kebijakan hukum yang memadai dan kapasitas yang diperlukan untuk menerapkan persyaratan peraturan saat ini dan mengurangi segala kelanjutan perdagangan ilegal di HCFC. Selain itu, komitmen kebijakan pemerintah dari atas ke bawah untuk menerapkan kekuasaan dan sanksi yang tersedia serta komitmen keuangan terhadap sumber daya yang diperlukan untuk melakukannya; (3) manajemen informasi; (4) penguatan pelatihan servis terkait Refrigeration dengan meningkatkan dan membangun kapasitas lembaga pendidikan nasional dan Bulgarian Branch Chamber- Machine; (5) mengembangkan rencana manajemen pengelolaan refrigerant perusahaan atau penggantian dan strategi manajemen refrigerant nasional.

Selanjutnya menurut Luttrell et. al (2014) pada penerapannya di Indonesia, program HCFC Phase-Out oleh UNDP disebut Hydrofluorocarbons Phase-Out Management Plan atau HPMP. Sebelum menerapkan Program HPMP di Indonesia. UNDP terlebih dahulu pernah menerapkan program serupa yang merupakan usaha pemerintahan lingkungan global yaitu program "Reducing Emissions from Deforestation and Forest Degradation" atau REDD+. Program tersebut telah berjalan di Indonesia sejak tahun 2010 didasari oleh Letter of Intent (LoI) antara Pemerintah Indonesia dan Norwegia sebagai negara utama donor dan difasilitasi oleh UNDP Indonesia (Luttrell, et al., 2014) Pelaksanaan REDD+ di Indonesia juga mengakibatkan reformasi kebijakan nasional dengan dikeluarkannya Keputusan Presiden (Keppres) Nomor 25 tahun 2011 dan Peraturan Presiden (Perpres) Nomor 62 tahun 2013 yang keduanya merupakan dasar dibentuknya badan untuk mengimpelementasikan REDD+ di Indoneisa. Sebelum dikeluarkannya 2 (dua) Perpres tersebut, Pemerintah Indonesia terebih dahulu mengeluarkan Instruksi Presiden Nomor 10 Tahun 2011 tentang Penundaan Pemberian Izin Baru dan Penyempurnaan Tata Kelola Hutan Alam Primer dan Lahan 
Gambut yang juga dikeluarkan sebagai tindaklanjut Program REDD+ di Indonesia (Purnomo, Luki, \& Suyamto, 2012).

Menurut Glover dan Schroeder (2016), untuk menjalankan program REDD+ di Indonesia dengan efektif, dibutuhkan legitimasi dari tiaptiap aktor terkait. Legitimasi tersebut terbagi atas legitimasi input dan legitimasi output (Glover \& Schroeder, 2016). Legitimasi input ada ketika aktor-aktor berkepentingan dilibatkan dalam pengambilan keputusan, sementara legitimasi output adalah ketika kebijakan-kebijakan diterima oleh masyarakat demi terselesaikannya isu. Pada implementasi REDD+, keterlibatan dari para aktor masyarakat atau aktor non-negara di legitimasi input menjadi sangat penting karena pada dasarnya aktor masyarakat atau aktor non-negara tidak terlalu memahami maupun merasakan langsung apa yang menjadi legitimasi output program dan keterlibatan masyarakat dalam legitimasi input dapat dipandang sebagai tujuan program itu sendiri bagi masyarakat (Glover \& Schroeder, 2016). Namun, kenyataannya, masih ada aktor-aktor masyarakat atau aktor non-negara yang terlewat pada proses legitimasi input program REDD+ (Glover \& Schroeder, 2016). Di sisi lain, aktor negara akan lebih berfokus pada output legitimasi karena hal tersebut dinilai sebagai hasil dan tujuan yang ingin dicapai dari REDD+itu sendiri (Glover \& Schroeder, 2016).

Serupa dengan proses implementasi Program REDD+, pada pembentukan regulasi nasional melalui program tersebut juga melibatkan banyak pihak. Menurut Luttrell, et al. (2012), secara garis besar terdapat tujuh badan yang berpengaruh dalam keberhasilan pembentukan dan implementasi regulasi nasional Indonesia melalui Program REDD+ yaitu: presiden, partai politik, birokrasi, interaksi antara sektor swasta dan kepentingan publik, pemerintah daerah, peran aktor internasional untuk memastikan kepemilikan nasional atas reformasi melalui program, peran aktor non-negara dalam mempopulerkan mandat untuk reformasi.

Menurut Sulistiawati (2014), pada Program REDD+ dapat dilihat peran eksternal dalam memengaruhi kebijakan nasional Indonesia, yang secara khusus terfokus pada 'donor project involvement'. Indikator tekanan atau peran eksternal dalam Program REDD++ dapat diikur pada beberapa indikator yaitu: persyaratan pendanaan, pengambilan keputusan dalam proyek, dan kegiatan pemantauan dan evaluasi dalam proyek, otoritas yang diterima oleh proyek, dan kegiatan yang dialokasikan untuk persiapan proses pengaturan melalui REDD+ oleh masing-masing proyek (Sulistiawati, 2014). Kemudian dari indikator-indikator ini, diasumsikan jika indikator ekstenal tinggi dalam pengukuran, akan mengakibatkan pengaruh yang tinggi dalam proses pengaturan dalam variabel dependen yaitu proses regulasi dengan indikator antara lain: kontribusi dalam anggaran oleh lembaga terkait, perubahan birokrasi di lembaga terkait, 
waktu yang dialokasikan oleh lembaga terkait, sumber daya manusia/staf yang didelegasikan dalam proyek oleh lembaga terkait (Sulistiawati, 2014).

Penerapan REDD+ di Indonesia oleh UNDP yang berperan sebagai kerangka pendamping dapat dijadikan acuan untuk bagaimana program HPMP kemudian diterapkan di Indonesia. Meskipun keduanya berada di ranah pemerintahan lingkungan global dan diterapkan oleh organisasi yang sama, kedua program tersebut memiliki objektif dan tujuan yang berbeda. Selain itu, implementasi Program REDD+ dan proses dalam pembentukan kebijakan nasional terkait program cenderung lebih kompleks. Untuk mencapai penjelasan yang lebih komprehensif lagi, penjelasan terkait penerapan HPMP akan melalui analisis menggunakan teori agar lebih memperlihatkan keberhasilan pembentukan regulasi nasional terkait Perlindungan Lapisan Ozon (PLO) yang sesuai dengan agenda Program HPMP.

Berbeda dengan pembahasan sebelumnya yang menunjukkan bagaimana keberhasilan program lingkungan yang serupa di Indonseia serta keberhasilan UNDP dalam mengimplementasikan programnya di negara-negara lain, tulisan ini menjawab pertanyaan bagaimana UNDP berhasil mengawal pembentukan kebijakan nasional Indonesia melalui program HPMP.

\section{Mekanisme Difusi Norma Internasional}

Dalam kerangka perspektif konstruktivisme, organisasi internasional biasanya dibentuk untuk membawa pengaruh positif terhadap tatanan dunia internasional dengan menjadi sumber norma dan legitimasi yang dapat berdampak pada perilaku negara. Diharapkan organisasi internasional dapat meningkatkan kerja sama, menyediakan tempat untuk perumusan kebijakan, dan mentransfer model tata kelola internasional (Barnett \& Finnemore, 1999). Pada titik tertentu, organisasi internasional memiliki kapabilitas untuk menyebarkan norma ke negara-negara anggota dan memberikan keahlian teknis khusus serta ide-ide normatif, misalnya akuntabilitas, transparansi, partisipasi publik, dan anti korupsi. Dengan demikian, norma tata kelola yang baik yang ditetapkan sebagai standar oleh suatu organisasi internasional dapat memengaruhi politik dalam negeri negara-negara anggota.

Menurut Alderson (2001), terdapat empat mekanisme yang dapat menjelaskan bagaimana organisasi internasional dapat mempromosikan reformasi kelembagaan dalam institusi pemerintahan, yaitu: (1) interaksi dengan aktor internasional; (2) bantuan ekonomi; (3) tekanan kompetitif antar negara; (4) perluasan komunitas internasional. Keempat mekanisme ini tidak harus dilakukan secara bersamaan, namun disesuaikan dengan kebutuhan dalam implementasi program yang telah disepakati bersama. 
Adapun mekanisme yang biasanya paling menentukan adalah adanya insentif dalam implementasi program dan kedekatan satu aktor dengan aktor yang lain sehingga terbentuk interaksi yang intensif. Sehingga dalam hal ini, bantuan ekonomi dan interaksi dengan aktor transnasional menjadi dua faktor utama yang berpengaruh dalam membantu pelembagaan norma internasional di level nasional.

Interaksi dengan aktor transnasional yang dalam hal ini termasuk di dalamnya adalah organisasi internasional, melibatkan pembelajaran sosial. Mekanismeinibekerja dengan memperkenalkannorma-normainternasional kepada negara-negara dan elit melalui interaksi yang dipimpin organisasi internasional (Brockhaus, 2012). Interaksi dapat berbentuk seminar, peningkatan kapasitas, dan pembagian pengetahuan. Hal ini dilakukan dengan harapan bahwa negara akan meniru dan menyesuaikan perilaku yang dianggap terhormat di tingkat internasional. Melalui mekanisme ini dapat menghasilkan difusi norma adalah sebagai contoh perubahan sikap individu sebagai akibat dari persuasi dan tekanan politik (Alderson, 2001).

Bantuan ekonomi atau pinjaman digunakan sebagai alat dengan pendekatan langsung untuk memberikan saran teknis agar terjadi reformasi. Bentuk bantuan ekonomi termasuk di dalamnya program penyesuaian struktural, skema persyaratan, dan jenis bantuan keuangan lainnya yang bersifat mengikat. Tujuan dari persyaratan dan penyesuaian struktural program adalah agar memungkinkan bagi donor untuk mempertanyakan struktur dan proses kebijakan negara-negara penerima bantuan serta untuk membuat mereka melakukan reformasi sesuai dengan kriteria dan kondisi universal yang ditetapkan oleh para donor (Doornbos, 2003). Bidang reformasi utama termasuk anggaran sektor publik, sistem hukum, reformasi layanan sipil, dan dukungan masyarakat sipil. Saran obyektif diberikan kepada pemerintah yang ingin menerima bantuan asing atau meminjam dari lembaga keuangan internasional dan pemberian bantuan ekonomi bergantung pada kinerja yang baik, untuk memastikan bahwa sumber daya yang disalurkan dapat digunakan dengan sebaik-baiknya (Brockhaus, 2012).

Setelah konsolidasi yang dilakukan dengan organisasi internasional tersebut, negara anggota memiliki tanggung jawab untuk melakukan sosialisasi negara. 'sosialiasi negara' didefnisikan oleh Alderson (2001) sebagai proses yang digunakan negara untuk menginternalisasi normanorma yang berasal dari tempat lain dalam sistem internasional. Dalam studi terkait sosialisasi negara, sebagaimana definisinya, berfokus pada bagaimana dan mengapa norma-norma asing diinternalisasi dalam suatu negara dan membawa sebab-sebab di semua tingkat analisis - individu, domestik, internasional - untuk menjawab pertanyaan-pertanyaan tersebut. Proses sosialisasi negara terbagi ke dalam tiga proses yang merupakan proses 
lepas dan dapat terjadi secara acak, yaitu (Alderson, 2001): pelembagaan, tekanan dan persuasi politik, dan perubahan keyakinan individu.

Institusionalisasi atau pelembagaan merupakan ciri khas dari proses sosialisasi negara. Beberapa strategi institusionalisasi tersedia untuk advokat norma domestik, antara lain: internalisasi hukum, penciptaan aktor untuk menegakkan norma-norma tertentu, dan tertanamnya norma di negara berdaulat. Internalisasi hukum terjadi ketika norma internasional dimasukkan ke dalam sistem hukum domestik melalui tindakan eksekutif, interpretasi yudisial, tindakan legislatif, atau kombinasi dari ketiganya (Koh, 1997). Semetara itu, penciptaan aktor birokrasi yang diberi mandat untuk menegakkan atau mempromosikan norma-norma tertentu menjadi standard operating procedures (SOP) birokratis untuk kelangsungan kebijakan negara. Selain itu, aktor birokrasi juga diharapakan dapat berperan untuk menjaga orientasi normatif dengan menjadi organisasi yang memastikan kelangsungan organisasinya sendiri dan akses organisasi ke sumber daya. Pada tingkat yang lebih dalam, pelembagaan mampu tertanam dan disebarluaskan ke seluruh bidang organisasi yang membentuk pemerintahan hingga menembus masyarakat di berbagai tingkatan. Sehingga pelembagaan tidak hanya mengubah insentif, tetapi juga membentuk kategori kognitif.

Dimensi kedua dari internalisasi normatif berkaitan dengan aspek politis negara, mengacu pada upaya aktor domestik seperti kelompok kepentingan domestik, pengusaha, legislator, dan pengadilan, untuk menekan atau membujuk pemerintah untuk mematuhi norma-norma internasional tertentu. Internalisasi politik dapat mengambil bentuk tekanan ataupun persuasi untuk melobi kepatuhan norma. Sementara itu, bentuk politik persuasi dilakukan oleh individu-individu seperti wirausahawan politik yang bersedia menginvestasikan sumber daya mereka dengan harapan pengembalian di masa denpan. Persuasi adalah aspek penting dri sosialisasi di mana individu dan kelompok individu berhasil dalam 'menjual' kebijakan yang diilhami oleh contoh-contoh asing. Proses Sosialisasi Negara merupakan proyek aktor sosial dan politik domestik serta proses yang terungkap di ranah internasional.

Perubahan keyakinan individu dapat dilihat ketika terjadi perubahan sikap pada seluruh komponen negara, dari badan pemerintahan, badan bisnis, institusi pendidikan, hingga masyarakat sipil. Perubahan sikap tersebut menujukkan bahwa suatu negara 'menginternalisasi' norma-norma yang muncul di tempat lain dalam sistem internasional. Interalisasi individu akan lebih cepat menghasilkan perubahan yang dramatis ketika individu yang terinternalisasi prinsip baru merupakan individu yang berpengaruh dalam tatanan negara. Pada tingkat analisis ini, cara psikologi kognitif dan sosial dapat membantu mengungkap mengapa individu megubah pikiran mereka tentang prinsip-prinsip penting, kepercayaan dan sikap. 
Berdasarkan penjabaran dari kerangka konseptual tersebut, maka alur pemikiran dalam artikel ini divisualisasikan oleh peneliti dalam gambar berikut:

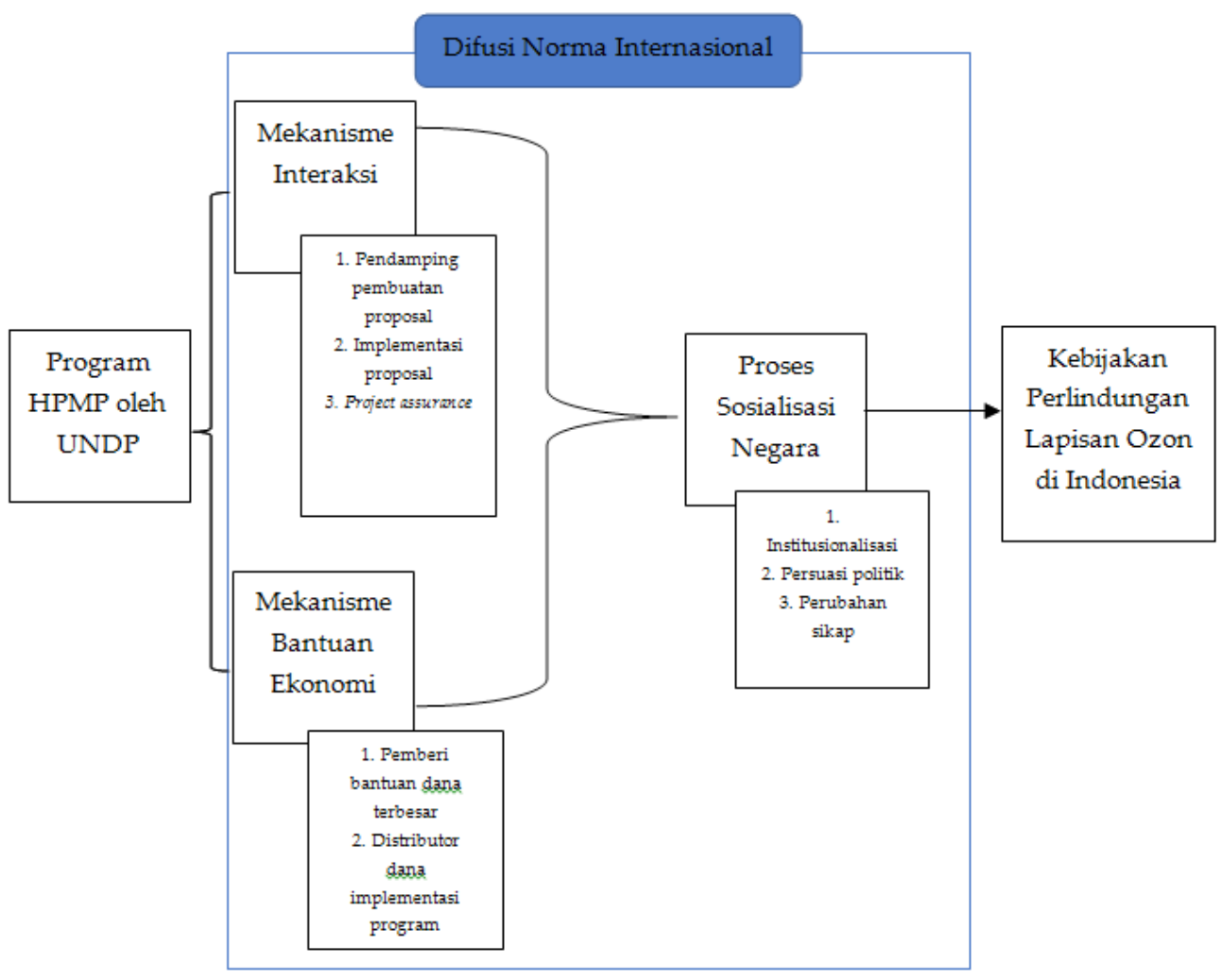

Gambar 1. Alur berpikir

\section{Interaksi Indonesia dengan UNDP dalam Program HPMP}

Agenda UNDP melalui Program HPMP yang diinternalisasi oleh Indonesia menjadi bentuk regulasi nasional dapat dijelaskan melalui teori yang dikemukakan oleh Alderson (2001) yaitu mekanisme difusi norma internasional yang kemudian dilanjutkan dengan proses sosialisasi negara. Dalam kasus ini, secara khusus, mekanisme difusi norma yang digunakan adalah mekanisme interaksi dengan aktor transnasional, yakni UNDP dan mekanisme bantuan ekonomi.

Interaksi antara Indonesia UNDP dapat dilihat ke dalam tiga fase, yakni: bantuan dalam pembuatan dan pengajuan proposal pelaksanaan program HPMP, pendampingan implementasi program dan pengawasan serta penjaminan berjalannya program. Pertama, peran UNDP dalam bentuk mekanisme interaksi dengan aktor transnasional di dalam implementasi Progam HPMP di Indonesia dapat dilihat sejak diajukannya proposal 
pelaksanaan Program tersebut. Pengajuan proposal ini dilakukan oleh UNDP sebagai lembaga pelaksana utama untuk implementasi Program HPMP di Indonesia pada Pertemuan Komite Eksekutif The Multilateral Fund for the Implementation of the Montreal Protocol ke-62 yang dilaksanakan pada 29 November hingga 3 Desember 2010 dengan salah satu agenda pembahasan yaitu pengajuan proposal pelaksanaan HPMP tahap 1 untuk Indonesia oleh UNDP. Proposal Program HPMP yang diajukan oleh UNDP kepada The Multilateral Fund for the Implementation of the Montreal Protocol atas nama pemerintah Indonesia kemudian berhasil disetujui oleh The Multilateral Fund pada Pertemuan Komite Eksekutif yang ke-64.

Disetujuinya proposal untuk implementasi Program HPMP di Indonesia tidak terlepas dari peran UNDP. Proposal yang diikuti dengan draf perjanjian yang kembali diajukan pada Pertemuan Komite Eksekutif ke-63 mendapat beberapa saran dari kelompok berkepentingan Komite Eksekutif untuk kemudian dipertimbangkan oleh Pemerintah Indonesia. Saran-saran tersebut antara lain: (1) merevisi jumlah total HCFC yang akan dihapus dalam implementasi HPMP; (2) pengenalan teknologi alternatif lain pada subsektor sektor pendingin udara dan sektor pendinginan; (3) serta mengatur prioritas sektor. Pembahasan terkait HPMP di Indonesia diteruskan dan ditindaklanjuti pada pertemuan Komite Eksekutif ke64 (UNEP, 2011). Hal ini kemudian ditindaklanjuti oleh UNDP dengan melakukan pertemuan-pertemuan dengan para pemangku kepentingan untuk membahas saran-saran yang diajukan oleh Komite Eksekutif. Salah satu langkah besar UNDP adalah berdiskusi dengan Ministry for Economy, Trade and Industry (METI) Jepang untuk mengajak bekerja sama dalam membujuk produsen utama peralatan pendingin udara di Jepang untuk mengadopsi teknologi alternatif yang lebih ramah lingkungan dalam konversi perusahaan manufaktur berbasis HCFC-22 di Indonesia (UNEP, 2011). Kerja sama antara Pemerintah Jepang dan UNDP kemudian menghasilkan pertemuan antara dua produsen utama yaitu Daikin dan Panasonic dengan perwakilan Permerintah Indonesia dan UNDP yang dilakukan pada 6 hingga 8 Juni 2011. Pertemuan ini dilakukan untuk membahas terkait penggunaan teknologi yang akan digunakan untuk mengurangi persebaran HCFC di Indonesia serta memperkenalkan teknologi baru sesuai dengan saran poin ke-2 dari Komite Eksekutif tentang pengenalan teknologi alternatif lain pada subsektor sektor pendingin udara dan sektor pendinginan.

Selain itu, UNDP juga membahas saran-saran dari Komite Eksekutif bersama dengan Pemerintah Indonesia mengingat saran-saran tersebut merupakan hal yang harus dipertimbangkan oleh Pemerintah Indonesia. Peran UNDP sebagai lembaga pelaksana utama untuk implementasi Program HPMP di Indonesia dibutuhkan dalam menanggapi saran-saran 
Komite Eksekutif agar respons Indonesia terhadap saran-saran tersebut sesuai dengan standar dan norma internasional. Respons-respons dari saran yang diajukan oleh Komite Eksekutif kemudian akan menjadi konteks perubahan dalam proposal Program HPMP yang akan kembali diajukan oleh UNDP atas nama Pemerintah Indonesia pada Pertemuan Komite Eksekutif ke-64. Setelah melakukan perubahan pada proposal sesuai saran Komite Eksekutif dan UNDP kembali mengajukan proposal untuk penerapan Program HPMP di Indonesia, pada Pertemuan Komite Eksekutif The Multilateral Fund for the Implementation of the Montreal Protocol ke-64 ditetapkan perjanjian antara Pemerintah Indonesia dengan The Multilateral Fund untuk pengurangan konsumsi hydrochlorofluorocarbons di Indonesia.

Pada tahap pembuatan proposal program, melaui interaksi dengan UNDP, Indonesia berhasil membentuk proposal yang sesuai dengan ketentuan The Multilateral Fund termasuk terkait tindaklanjut dan respons dari saran-saran yang diberikan oleh The Multilateral Fund. Sehingga proposal yang diajukan untuk implementasi Program HPMP di Indonesia dapat mencapai ketetapan perjanjian antara Pemerintah Indonesia dengan The Multilateral Fund. Pembentukan proposal yang melibatkan interaksi pihak Pemerintah Indonesia dengan UNDP mendorong adanya transfer pengetahuan terkait sistematika dan model tata kelola yang tertera dalam proposal Program HPMP untuk kemudian direalisasikan oleh Pemerintah Indonesia melalui Kementerian Kehutanan dan Lingkungan Hidup (KLHK) dan National Ozone Unit (NOU).

Kedua, mekanisme interaksi Indonesia dengan aktor transnasional yaitu UNDP yang dapat mendorong keberhasilan pembentukan kebijakan nasional Indonesia terkait Perlindungan Lapisan Ozon (PLO) lebih lanjut dapat dianalisis dalam implementasi program. Sebagai lembaga pelaksana utama, interaksi UNDP dengan Indonesia diatur dalam perjanjian antara Indonesia dan The Multilateral Fund for the Implementation of the Montreal Protocol terkait implementasi HPMP di Indonesia yang dibahas pada pertemuan Komite Eksekutif The Multilateral Fund for the Implementation of the Montreal Protocol ke-64 yang diadakan di Montreal pada 25-29 Juli 2011 (UNEP, 2011). Peran UNDP dalam Program HPMP di Indonesia, antara lain mencakup: 1) Memastikan kinerja dan verifikasi keuangan sesuai dengan yang tertera dalam perjanjian dan dengan prosedur serta persyaratan internal sebagaimana yang tercantum dalam rencana phase-out milik Indonesia; 2) Membantu Indonesia dalam mempersiapkan rencana dan laporan implementasi sesuai dengan ketentuan yang berlaku; 3) Memberikan verifikasi kepada Komite Eksekutif bahwa target tahunan telah terpenuhi dan kegiatan tahunan telah selesai dilaksanakan sesuai dengan rencana implementasi program; 4) Memastikan bahwa kemajuan terlihat dalam rencana implementasi program dengan menunjukkan refleksi 
pembelajaran dalam program dan konsistensi pelaksanaan program; 5) Memenuhi persyaratan pelaporan untuk rencana keseluruhan program sesuai dengan ketentuan dalam perjanjian. Syarat pelaporan meliputi pelaporan terkait kegiatan yang dilakukan oleh badan-badan yang bekerja sama; 6) Memastikan bahwa pakar teknis independen melakukan tinjauan teknis; 7) Melakukan pengawasan sesuai dengan yang diperlukan; 8) Memastikan adanya mekanisme operasi yang memungkinkan implementasi program yang efektif, transparan dan memiliki laporan data yang akurat sebagaimana rencana program; 9) Mengkoordinasikan kegiatan UNIDO, Bank Dunia, dan Pemerintah Australia sebagai instansi pendukung kerja sama dan memastikan urutan kegiatan yang tepat untuk implementasi kegiatan; 10) Bekerja sama dengan instansi-instansi pendukung yaitu UNIDO, Bank Dunia, dan Pemerintah Australia sesuai dengan ketentuan yang berlaku di dalam perjanjian; 11) Memastikan bahwa penyaluran dana oleh instansi pendukung untuk Indonesia mengacu pada indikator; dan 12) Memberikan bantuan terkait kebijakan, manajemen, dan dukungan teknis jika diperlukan.

Dua belas poin peran UNDP dalam Program HPMP di Indonesia memilikitujuanutamayaitu pendampingan terhadapimplementasiprogram sehingga Indonesia dapat berhasil mencapai tujuan yang telah disepakati dalam perjanjian antara antara Pemerintah Indonesia dan Komite Eksekutif The Multilateral Fund untuk pengurangan konsumsi hydrochlorofluorocarbons di Indonesia. Dalam implementasinya, peran UNDP dilakukan melalui dua media yaitu inklusivitas Program HPMP di Indonesia yang menempatkan UNDP sebagai project assurance di dalam struktur organisasi program dan pertemuan tahunan yang mempertemukan UNDP, KLHK, para pemangku kepentingan dan mitra-mitra lainnya termasuk sektor privat.

Ketiga, peran UNDP dalam mekanisme interaksi untuk implementasi program selanjutnya dilaksanakan melalui keterlibatannya di dalam struktur organisasi Program HPMP di Indonesia dengan posisi UNDP sebagai project assurance. Keterlibatan UNDP sebagai poroject assurance menjadi bentuk peran UNDP secara langsung untuk membantu Indonesia dalam mempersiapkan rencana dan laporan sesuai dengan perjanjian dan ketentuan. Melalui peran tersebut, Indonesia akan secara disiplin mematuhi dan menerapkan norma-norma internasional yang berusaha diterapkan oleh UNDP di Indonesia. Dalam kegiatan UNDP sebagai project asusrance, penting bagi UNDP untuk memperhatikan ketentuan dan perjanjian yang telah disepakati oleh Indonesia dan The Multilateral Fund, baik ketentuan yang harus dipatuhi dalam pelaksanaan implementasi program maupun dalam ketentuan dalam perencanaan dan laporan. UNDP bertanggung jawab melakukan pengawasan dan memastikan bahwa Indonesia dalam implementasi program HPMP di negaranya telah mematuhi ketentuan dan 
perjanjian tersebut. Selain itu, melalui posisi sebagai project assurance, UNDP memiliki kapabilitas untuk berinteraksi dengan Indonesia dalam bentuk keterlibatan langsung di dalam program untuk memberikan bantuanbantuan non-materil seperti bantuan perancangan kebijakan yang akan berpengaruh pada tercapainnya norma-norma internasional yang sesuai perjanjian.

Di sisi lain, pertemuan tahunan akan menjadi media untuk UNDP berperan dalam hal-hal yang berkaitan dengan perencanaan, finalisasi dan verifikasi. Pertemuan tahunan merupakan pertemuan yang melibatkan seluruh institusi yang terlibat di dalam implementasi Program HPMP dan dilaksanakan paling sedikit dua kali setiap tahun dengan setidaknya satu pertemuan diselenggarakan sebelum tanggal penyerahan rencana implementasi dan laporan Program HPMP di Indonesia kepada Komite Eksekutif. Melalui pertemuan tahunan UNDP sebagai lembaga pelaksana utama dapat melakukan pertemuan formal secara rutin dan kontinu, dengan mengikutsertakan semua insitusi yang terlibat mulai dari pemerintahan hingga sektor privat untuk membahas keseluruhan implementasi program yang secara umum mencakup perencanaan, implementasi dan pelaporan. Sehingga peran UNDP mulai dari pemastian perencanaan, finalisasi hingga dilakukannya verifikasi dalam rencana program hingga laporan program dilakukan di dalam pertemuan tersebut.

Kegiatan verifikasi yang dilakukan dalam pertemuan tahunan oleh UNDP akan mendorong Indonesia untuk mengikuti standar dan norma internasional yang telah ditetapkan. Pemastian dan verifikasi Program HPMP mulai dari perencanaan hingga pembentukan laporan program akan mendorong Indonesia untuk mengikuti standar dan norma sesuai ketetapan UNDP dalam kegiatan pemastian dan verifikasinya yang mengacu pada ketentuan dan perjanjian di bawah The Multilateral Fund. Sehingga pemastian dan verifikasi yang dilakukan oleh UNDP memberikan standar normatif pada implementasi yang dilakukan oleh seluruh komponen nasional yang terlibat khususnya Kementerian Kehutanan dan Lingkungan Hidup (KLHK) dan National Ozone Unit (NOU) sebagai institusi di bawah Pemerintah Indonesia yang bertanggung jawab atas manajemen program.

Mekanisme interaksi dengan aktor transnasional dalam hal ini yaitu UNDP dan mekanisme bantuan ekonomi merupakan mekanisme yang saling berhubungan, berpengaruh dan mendukung berjalannya mekanisme satu sama lain. Melalui mekanisme interaksi dengan aktor transnasional, UNDP mendorong Indonesia untuk mengikuti norma yang dianggap baik di tingkat internasional serta melakukan pendampingan yang berdampak pada peningkatan pengetahuan dan kapabilitas Indonesia untuk menyesuaikan dengan norma tersebut. 
Sebelum terbentuknya regulasi nasional terkait perlindungan lapisan ozon (PLO) di Indonesia, telah diadakan satu kali Pertemuan The Multilateral Fund yang salah satu agendanya membahas laporan implementasi program HPMP di Indonesia. Pertemuan tersebut merupakan Pertemuan Komite Eksekutif The Multilateral Fund for the Implementation of the Montreal Protocol ke-71 yang diadakan di Montreal pada 2-6 Desember 2013. Hasil tinjauan Komite Eksekutif terhadap laporan yang disajikan oleh Indonesia dalam mencatat penghargaan atas keberhasilan berkelanjutan atas penghapusan Bahan Perusak Ozon (BPO) dan penghapusan CFC berkelanjutan yang telah dilakukan oleh Indonesia (UNEP, 2013). Dalam pertemuan tersebut, Komite Eksekutif mencatat bahwa Indonesia berhasil menerapkan berbagai inisiatif kebijakan dan peraturan untuk pemantauan dan pengendalian BPO yang efektif dan menunjukkan keberhasilan koordinasi dengan lembaga dan pemangku kepentingan nasional lainnya dalam memantau implementasi program penghentian BPO yang semuanya akan membantu negara dalam mencapai target penghapusan HCFC (UNEP, 2013). Komite Eksekutif menyatakan harapan bahwa Indonesia akan terus berkoordinasi untuk menerapkan kebijakan dan peraturan sehingga dapat mempertahankan aktivitas penghapusan $\mathrm{BPO}$, memperkuat kapasitas manajemen nasional dan meningkatkan peraturan perundang-undangan dan sistem perizinan BPO untuk mencapai target kepatuhan di 2013 dan 2015.

\section{Bantuan Ekonomi kepada Indonesia}

Pada mekanisme bantuan ekonomi, perjanjian antara Pemerintah Indonesia dan Komite Eksekutif The Multilateral Fund untuk pengurangan konsumsi hydrochlorofluorocarbons di Indonesia juga menjadi awal persetujan skema pembiayaan yang diberikan oleh UNDP sebagai salah satu sumber dana implementasi Program HPMP di Indonesia. Di antara beberapa instansi yang turut berkontribusi terhadap pembiayaan Program HPMP Indonesia, UNDP sebagai lembaga pelaksana utama memberikan bantuan ekonomi terbesar untuk implementasi program dibandingkan dengan instansi-instansi lain yang bertindak sebagai instansi pendukung (Tabel 1).

Peran UNDP dalam mekanisme bantuan ekonomi adalah: pertama, sebagai pemberi dana terbesar; dan kedua, sebagai lembaga yang mendistribusikan dana tersebut. Mengingat dengan besaran jumlah bantuan ekonomi yang diberikan oleh UNDP untuk pembiayaan implementasi program akan berbanding lurus dengan jumlah target ODP-ton BPO yang dihapuskan menggunakan pembiayaan, maka UNDP sendirilah yang berperan sebagai pemberi bantuan ekonomi terbesar bagi Indonesia. Hal ini dilakukan sehingga peran mekanisme bantuan ekonomi yang dilakukan oleh UNDP menjadi signifikan, baik secara jumlah pembiayaan maupun angka penghapusan ODP-ton BPO. Dengan bantuan ekonomi yang 
diberikan oleh UNDP, Indonesia ditargetkan menghapuskan sebanyak 86.78 OPD-ton BPO dari jumlah keseluruhan penghapusan BPO melalui program yaitu sebanyak 131.20 ODP-ton (UNEP, 2011). Sesuai dengan jumlah persentase pembiayaan yang bersumber dari UNPD, target jumlah BPO yang dihapuskan dari pembiayaan tersebut juga melebihi 50\% jumlah keseluruhan target penghapusan $\mathrm{BPO}$ yang tertera di dalam perjanjian.

Selain UNDP, ada juga instansi-instansi pendukung dalam implementasi Program HPMP di Indonesia sesuai dengan perjanjian antara antara Pemerintah Indonesia dan Komite Eksekutif antara lain adalah UNIDO, Bank Dunia dan Pemerintah Australia. Rincian pembagian bantuan ekonomi yang terbagi ke dalam 2 (dua) komponen biaya yaitu Dana Pembiayaan dan Biaya Dukungan Lembaga yang kemudian akan didistibusikan per-periode sesuai dengan perjanjian yang telah disepakati (Tabel 1). Pendanaan dengan jumlah terbesar yang dilakukan oleh UNDP akan dialokasikan untuk 3 (tiga) unsur program yaitu unsur sektor pendingin udara, unsur sektor pendinginan serta unsur manajemen dan koordinasi.

Tabel 1. Jumlah bantuan ekonomi per-instansi dan per-periode yang telah disepakati (UNEP, 2011).

\begin{tabular}{|c|c|c|c|c|c|c|c|}
\hline No & Instansi & Komponen & 2011 & 2013 & 2015 & 2018 & Total \\
\hline & UNDP (Lenb aga Pelahsara Utama) & Dara Pembiayaan & $4,000,000$ & $4,000,000$ & 456,102 & 445,000 & $8,901,102$ \\
\hline & & $\begin{array}{l}\text { Biaya Dukungan } \\
\text { Lembaga }\end{array}$ & 300,000 & 300,000 & 34,208 & 33,375 & 667,583 \\
\hline \multirow[t]{2}{*}{2} & Pemeritah.Australia & Dara Pembiayaan & 300,000 & - & - & - & 300,000 \\
\hline & & $\begin{array}{l}\text { Biaya Dukoungan } \\
\text { Lembaga }\end{array}$ & 39,000 & - & - & - & 39,000 \\
\hline \multirow[t]{2}{*}{3} & Bank Duria & Dara Pembizyaan & $1,500,000$ & 942,767 & 135,710 & 135,710 & $2,714,187$ \\
\hline & & $\begin{array}{l}\text { Biaya Dukungan } \\
\text { Lembaga }\end{array}$ & 112,500 & 70,708 & 10,178 & 10,178 & 203,564 \\
\hline & UNDO & Dana Pembiayaan & 777,395 & - & - & - & 777,395 \\
\hline & & \begin{tabular}{|l} 
Biaya Dukungan \\
Lembaga
\end{tabular} & 58,305 & - & - & - & 58,305 \\
\hline \multicolumn{3}{|c|}{ TotalDana Penbiayaan } & $6,577,395$ & $4,942,767$ & 591,812 & 580,710 & $12,692,684$ \\
\hline \multirow{2}{*}{\multicolumn{3}{|c|}{ TotalBiaya Dulangan Lenbaga }} & 509,805 & 370,708 & 44,386 & 43,553 & 968,452 \\
\hline & & & $7,087,200$ & $5,313,475$ & 636,198 & 624,263 & $13,661,136$ \\
\hline
\end{tabular}

Selanjutnya dalam mekanisme bantuan ekonomi, UNDP juga berperan sebagai lembaga yang mendistribusikan bantuan ekonomi untuk implementasi Program HPMP di Indonesia. Bantuan ekonomi yang bersumber dari UNDP, UNIDO, Pemerintah Australia dan Bank Dunia dihimpun di bawah The Multilateral Fund dan kemudian didistribusikan untuk implementasi program di Indonesia melalui UNDP sebagai lembaga pelaksana utama. Hingga terbentuknya regulasi nasional Indonesia terkait perlindungan lapisan ozon (PLO) dan penghapusan BPO di tahun 2015, jumlah bantuan ekonomi yang telah didistribusikan oleh UNDP untuk implementasi program yaitu sebanyak US \$4,649,597 (UNFPA, 2015). Peran UNDP dalam mendistribusikan bantuan ekonomi untuk implementasi Program HPMP menjadi posisi yang krusial dalam pencapaian tujuan program. Dengan peran tersebut, UNDP bertanggung jawab terhadap 
distribusi bantuan ekonomi yang efektif dengan tetap mengacu pada perjanjian, ketentuan dan skema yang telah ditetapkan. Sebagai lembaga yang mendistribusikan bantuan di dalam program UNDP harusmembangun langkah yang mampu mendorong agar bantuan ekonomi dapat secara efektif mengarah pada tercapainya tujuan implementasi program.

Penyaluran pembiayaan untuk implementasi program HPMP di Indonesia dari penghimpun sumber pembiayaan yaitu The Multilateral Fund, dilakukan melalui UNDP sebagai lembaga pelaksana utama serta lembaga bagian dari The Multilateral Fund yang melakukan pendampingan implementasi Program HPMP di Indonesia. Dana yang bersumber dari The Multilateral Fund kemudian didistribusikan oleh UNDP kepada KLHK atau NOU dan sektor privat atau pengusaha-pengusaha sebagai institusiinstitusi nasional yang secara langsung menjalankan program HPMP dan berupaya untuk mencapai tujuan program (Gambar 1).

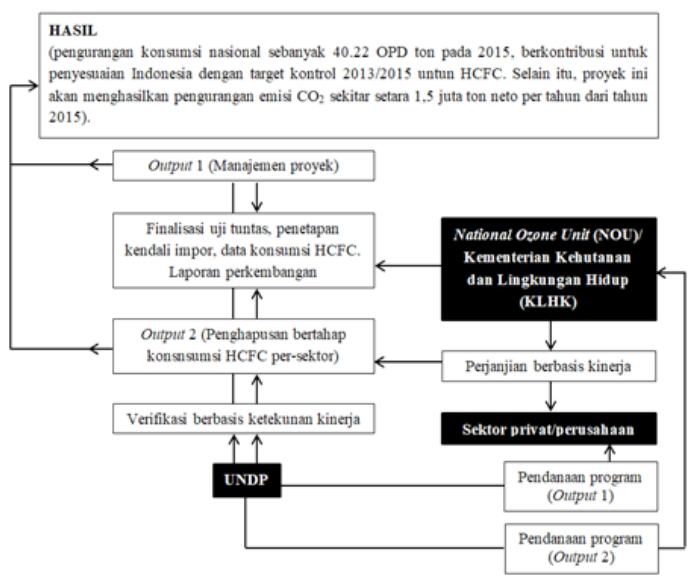

Gambar 2. Skema Distribusi Dana Program HPMP dan Tujuan Hasil Pendanaan Program (Kementerian Keuangan, 2012).

Pemberian bantuan ekonomi untuk implementasi Program HPMP di Indonesia dilakukan per-periode disertai dengan ketentuan-ketentuan yang juga tertera dalam perjanjian. Ketentuan tersebut ditujukan agar implementasi Program HPMP di Indonesia yang pelaksanaannya didukung oleh The Multilateral Fund, khususnya UNDP sebagai lembaga pelaksana utama berhasil mencapai tujuan program saat terselesaikannya program. Dengan adanya ketentuan-ketentuan sebagai syarat untuk didistribusikannya pembiayaan program, implementasi program HPMP di Indonesia akan tetap berada di jalur yang sesuai dengan standar-standar normatif yang telah ditentukan dan berusaha ditransfer oleh UNDP ke Indonesia. Kepatuhan Indonesia terhadap standar normatif tersebut menjadi acuan bagi The Multilateral Fund untuk mendistribusikan bantuan ekonomi untuk implementasi Program HPMP di Indonesia yang dilakukan 
melalui UNDP. Sehingga menjadi kewajiban UNDP sebagai lembaga pelaksana utama untuk memastikan bahwa Indonesia mengikuti standarstandar normatif di bawah program.

Mekanisme bantuan ekonomi menjadi insentif agar Program HPMP di Indonesia dapat berhasil mencapai tujuan. Peran UNDP dalam mekanisme bantuan ekonomi utamanya dilakukan dalam dua bentuk yaitu sebagai sumber terbesar bantuan ekonomi dan sebagai lembaga yang bertanggung jawab untuk melakukan distribusi atas bantuan ekonomi untuk implementasi Program HPMP di Indonesia. Pemberian bantuan ekonomi menjadi sumber pembiayaan seluruh kegiatan program sehingga mekanisme bantuan ekonomi dalam implementasi Program HPMP di Indonesia merupakan komponen penting yang berpengaruh terhadap implementasi dan pencapaian tujuan program. Dengan pembiayaan tersebut, Indonesia sebagai salah satu negara Artikel 5 dapat mematuhi norma internasional terkait penghapusan $\mathrm{BPO}$ dan perlindungan lapisan ozon (PLO). Tanpa mekanisme bantuan ekonomi, implementasi program tidak akan berjalan secara efektif atau bahkan sama sekali tidak berprogres yang kemudian akan mengakibatkan tujuan tidak dapat tercapai.

Melalui dua mekanisme yaitu mekanisme interkasi dengan aktor transnasional dan mekanisme bantuan ekonomi, UNDP memberikan intensif politik dan ekonomi kepada Indonesia agar Indonesia dapat melakukan penghapusan terhadap BPO terutama HCFC-22 dan HCFC144b sesuai dengan norma internasional yang ditetapkan dan disetujui oleh Indonesia. UNDP menerapkan tata kelola untuk menetapkan standar perliaku yang sesuai dengan norma internasional yang dapat memengaruhi aktivitas dan politik dalam negeri agar dapat menyesuaikan dengan norma dan aturan internasional terkait. Mekanisme yang dilakukan oleh UNDP di Indonesia berhasil mendorong Indonesia untuk melakukan penghapusan BPO dengan ketentuan-ketentuan yang sesuai dengan perjanjian antara perjanjian antara Indonesia dan The Multilateral Fund for the Implementation of the Montreal Protocol (IMF, 2015).

\section{Sosialisasi Negara dalam Regulasi PLO}

Mekanisme interkasi dengan aktor transnasional dan mekanisme bantuan ekonomi sebagai bentuk mekanisme difusi norma dalam Program HPMP yang diimplementasikan oleh UNDP di Indonesia mentransfer berbagai norma yang kemudian diinternalisasi oleh Indonesia sebagai institusi berdaulat melalui Proses Sosialisasi Negara. Bersamaan dengan dimulainya mekanisme interaksi dan mekanisme bantuan ekonomi, Proses Sosialisasi Negara dalam Program HPMP di Indonesia dimulai pada tahapan perencanaan program dan proses pengajuan proposal untuk implementasi Program HPMP di Indonesia kepada The Multilateral Fund for the Implementation of the Montreal Protocol. 
Pertama adalah tahapan institusionalisasi melalui pembentukan National Ozone Unit (NOU). Pada tahapan perencanaan program dan proses pembuatan proposal, di bawah Kementerian Kehutanan dan Lingkungan Hidup (KLHK), Indonesia membentuk NOU yang menjadi titik fokus nasional untuk implementasi Montreal Protocol dan bertanggung jawab atas keseluruhan koordinasi program penghapusan BPO di Indonesia. Terbentuknya NOU sebagai badan nasional Indonesia yang memiliki fungsi pengawasan dan koordinasi untuk implementasi HPMP di Indonesia merefleksikan bahwa nilai-nilai pengawasan untuk standar perilaku tertentu yang sesuai dengan norma internasional telah ditransfer ke tingkat nasional Indonesia. Sehingga UNDP telah berhasil menjadi sumber norma untuk pemerintahan berkualitas yang salah satunya ditunjukan dengan adanya badan pengawas implementasi program ke Pemerintahan Indonesia untuk penghapusan BPO.

Di bawah KLHK, NOU sebagai lembaga yang secara khusus dibentuk untuk implementasi program HPMP di Indonesia mengepalai proses pengembangan program yang bertujuan untuk meninjau informasi dan menganalisis data dari setiap sektor yaitu Sektor Pendingin Udara, Pendinginan, Buih dan Pemadam Kebakaran. Bekerja sama dengan UNDP dan didukung oleh para pakar nasional, NOU mengoordinasikan sektor-sektor yang menjadi fokus penghapusan BPO di Indonesia untuk mendapatkan informasi dan menganalisis data yang mencakup jumlah pengurangan konsumsi, rencana penggunaan teknologi alternatif serta biaya yang dibutuhkan untuk kemudian ditindaklanjuti dengan membentuk konsep strategi nasional dan rencana aksi menyeluruh sehingga Indonesia dapat mematuhi target kontrol 2013/2015 untuk konsumsi HCFC melalui Program HPMP. Seluruh informasi, analisis data dan strategi nasional menjadi bahan pembuatan proposal implementasi Program HPMP di Indonesia yang akan diajukan kepada The Multilateral Fund for the Implementation of the Montreal Protocol untuk mencapai ketetapan perjanjian implementasi program.

Proses Sosialisasi Negara pada tahapan institusionalisasi dilanjutkan dengan pembentukan mitra pelaksana dalam implementasi Program HPMP di Indonesia yaitu The Deputy for Environmental Degradation Control and Climate Change akan menjadi badan yang mengimplementasikan program atas nama Pemerintah Indonesai dan bertanggung jawab penuh atas kesuksesan manajemen dan koordinasi program dan penghapusan HCFC dalam Program HPMP. Bersama dengan UNDP dan institusiinstitusi nasional meliputi Kementerian Kehutanan dan Lingkungan Hidup, Kementerian Perindustrian, Kementerian Pedagangan, Ditjen Bea dan Cukai, Statistik, dan Industri, The Deputy for Environmental Degradation Control and Climate Change yang tergabung dalam Project Board akan 
bertanggung jawab dalam pengambilan keputusan untuk pelaksanaan pekerjaan dan revisi.

The Deputy for Environmental Degradation Control and Climate Change akan menunjuk the Assistant Deputy for Climate Change Mitigation and Atmosphere Function Conservation sebagai National Project Directior (NPD) untuk memikul tanggung jawab dalam implementasi harian Program HPMP di Indonesia. NPD memiliki kapabilitas untuk membangun kontrak dengan pihak lain untuk menangani aktivitas tertentu dengan tetap mengacu pada standard operating procedures (SOP) yang telah ditentukan. Rangkaian tugas dan tanggung jawab NPD akan dibantu oleh The Deputy National Project Director (DNPD) dan dipastikan oleh National Project Manager (NPM) dan tiga tim yang dibentuk untuk secara fokus mengawasi elemen-elemen tertentu dalam program yaitu tim dukungan proyek, tim teknis untuk Sektor Pendingin Ruangan, dan tim teknis untuk Sektor Pendinginan.

Kedua, setelah tahapan institusionalisasi ada proses tekanan dan perusasi politik. Pada strategi dan implmenetasi Program HPMP di Indonesia, penting untuk dicatat bahwa Indonesia mengadopsi pendekatan bottom-up (UNEP, 2011) yang menekankan pada kolaborasi erat dengan industri yang terlibat di dalam program. Kehadiran konsultasi yang panjang dan intensif antara pemerintah dan industri dengan pendampingan UNDP serta pertemuan tahunan yang mengikutsertakan seluruh instansi terlibat termasuk sektor privat dan pihak industri membangun Program HPMP yang bersifat kolaboratif dan inklusif. Strategi komunikasi antara lembaga pelaksana utama yaitu UNDP di tingkat internasional dan KLHK serta NOU di tingkat nasional juga didukung dengan adanya analisis tingkat subsektor yang menyeluruh dari sektor-sektor konsumsi HCFC yang terbagi menjadi empat sektor yaitu Sektor Pendingin Udara, Sektor Pendinginan, Sektor Buih, dan Sektor Pemadam Kebakaran dengan jumlah industri dan total pembiayaan yang berbeda dalam masing-masing sektor sehingga komunikasi yang menyeluruh pada tingkat industri di dalam program juga efisien karena memiliki fokus yang terbagi pada masing-masing sektor.

Adanya sistem pemberian dana langsung kepada pihak industri terlibat oleh UNDP akan saling mendukung dengan kegiatan komunikasi dan konsultasi yang telah dijalankan sejak masa perencanaan program dan usaha pengajuan proposal kepada The Multilateral Fund. Mekanisme ini kemudian membangun kesiapan industri dari setiap sektor untuk berada di bawah standar normatif dalam Program HPMP. Norma-norma dan pola perilaku yang sesuai dengan standar normatif internasional terkait pembatasan jumlah konsumsi BPO seperti penggunaan teknologi alternatif dan pelatihan sumber daya manusia untuk menyesuaikan teknologi alternatif tersebut telah diterapkan oleh industri-industri melalui dorongan Program HPMP dan menjadi bentuk persuasi yang mendorong serta mendukung Indonesia untuk secara menyeluruh mencapai tujuan Program HPMP. 
Tekanan dan persuasi politik salah satunya dapat dilihat dari aktivitas perusahaan Daikin sebagai perusahaan yang termasuk ke dalam produsen utama untuk produk penghasil BPO di Indonesia. Komunikasi dan kerja sama yang telah terbangun sejak proses pembuatan proposal rencana implementasi Program HPMP di Indonesia antara pihak pemerintah Indonesia dan UNDP dengan pihak Daikin telah membangun kesadaran dan kesiapan pihak Daikin untuk bekerja sama mengadopsi norma-norma internasional di bawah Program HPMP. Pada tahun 2014, PT Daikin Airconditioning Indonesia telah meluncurkan sejumlah produk pendingin udara yang menggunakan refrigeran R32 sebagai zat pendingin yang ramah lingkungan dan sesuai dengan kesepakatan di bawah Program HPMP. Sebelum dilakukannya peluncuran tersebut, perusahaan juga mengadakan persiapan berupa sosialisasi melalui seminar untuk penjual dan kontraktor instalasi di seluruh Indonesia sehingga ada pemastian bahwa semua pemasang dan kontraktor telah memenuhi syarat untuk memasang pendingin ruangan dengan teknologi R32 dan semua pekerjaan instalasi berjalan aman. Dengan peluncuran produk-produk tersebut, PT Daikin Airconditioning Indonesia menjadi perusahaan pendingin udara pertama yag meluncurkan produk pendingin udara dengan refrigeran 32 dan menunjukkan kesiapan PT Daikin yang secara tidak langsung akan menciptakan bentuk persuasi politik.

Tahapan ketiga adalah perubahan sikap atau keyakinan masyarakat. Perubahan sikap secara menyeluruh di Indonesia untuk norma internasional terkait langkah perlindungan lapisan ozon dan pembatasan jumlah BPO merupakan tahapan proses sosialisasi negara yang menunjukkan bahwa norma-norma internasional tersebut telah diinternalisasi oleh Indonesia sebagai negara berdaulat. Internalisasi secara menyeluruh di Indonesia dapat ditandai dengan terciptanya regulasi di tingkat kementerian yaitu Peraturan Menteri Perindustrian Nomor: 41/M-Ind/Per/5/2014 tentang Larangan Penggunaan HCFC di Bidang Perindustrian dan Peraturan Menteri Perdagangan Nomor: 55/M-Dag/Per/9/2014 tentang Impor Barang Berbasis Pendingin. Kedua regulasi yang mulai diterapkan pada tahun 2015 merupakan langkah Indonesia yang menunjukkan bahwa seluruh komponen negara yang berhubungan dengan norma-norma tersebut, khususnya instansi pemerintahan dan bisnis telah siap untuk menyesuaikan sikap sesuai dengan norma-norma internasional yang diterapkan melalui Program HPMP. Mekanisme bantuan ekonomi dan mekanisme interaksi dengan aktor transnasional yang kemudian menghasilkan internalisasi norma internasional dalam Proses Sosialisasi Negara berujung pada perubahan sudut pandang dalam seluruh komponen negara yang juga merupakan salah satu tahapan Sosialisasi Negara. 
Implementasi Program HPMP di Indonesia yang bersifat inklusif untuk setiap institusi yang terlibat mendorong perubahan sudut pandang dari tiap-tiap individu berpengaruh di instansi-instansi tersebut. Selain itu, peran instansi-instansi utama dalam Program HPMP yaitu KLHK, NOU dan UNDP yang membangun koordinasi dan manajemen program yang terorganisir mulai dari perencanaan tahunan program hingga kerangka kegiatan pemantauan dan evaluasi program sehingga instansi-instansi yang berada di bawah koordinasi dan manajemen tersebut cenderung untuk mengikuti dan menyesuaikan pola perilaku serta mengubah sudut pandang sesuai dengan implementasi Program HPMP di Indonesia.

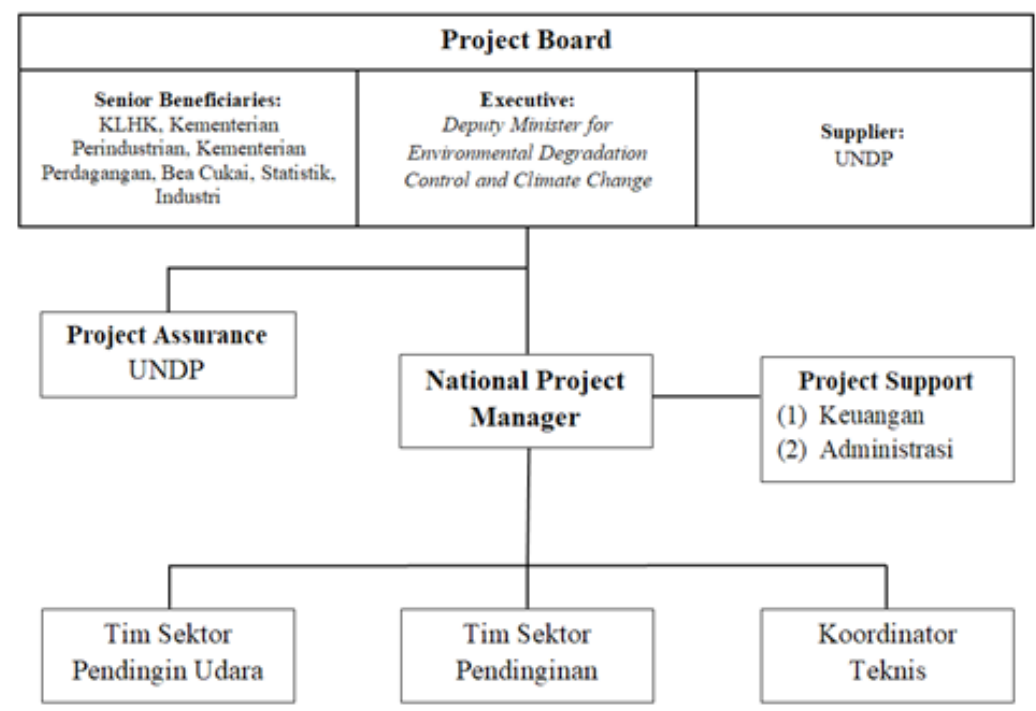

Gambar 3. Struktur Organisasi Proyek (Kementerian Keuangan, 2012).

Koordinasi dan manajemen implementasi program yang inklusif pada implementasi Program HPMP di Indonesia pada tingkat nasional juga didukung dengan adanya pertememuan yang melibatkan UNDP, KLHK, seluruh pemangku kepentingan dan mitra yang diadakan setidaknya dua kali dalam setahun untuk membahas perencanaan dan evaluasi program. Melalui pertemuan tersebut, seluruh pemangku kepentingan dan mitra akan mendapatkan informasi yang valid terkait program terutama tentang perencanaan implementasi program sehingga seluruh komponen dapat mengetahui langkah selanjutnya dalam program dan ada kecenderungan untuk mendukung perencanaan serta tujuan program dengan mengubah pola perilaku dan ikut menaati norma-norma internasional yang berusaha dimasukkan melalui Program HPMP ke Indonesia. Selain itu, keterbukaan terkait berbagai kegiatan yang telah dijalankan di dalam program kepada seluruh instansi terkait juga meningkatkan kepercayaan dari instansiinstansi tersebut untuk menyesuaikan norma dan pola perilaku. 


\section{Kesimpulan}

Melalui Program HPMP, UNDP berhasil memasukkan norma-norma internasional menjadi bentuk regulasi nasional Indonesia. Keberhasilan pembentukan regulasi nasional Indonesia melalui Program HPMP dicapai dengan penerapan dua mekanisme difusi norma internasional yaitu mekanisme interaksi dan mekanisme bantuan ekonomi. Melalui kedua mekanisme tersebut UNDP melakukan peran-peran untuk mentransfer norma-norma internasional kepada Indonesia sehingga Indonesia dapat menjalankan dan mencapai Program HPMP sesuai dengan agenda UNDP. Kegiatan mekanisme interaksi dilakukan dengan tiga cara yaitu peran UNDP sebagai pendamping dalam pembuatan dan pengajuan proposal pelaksanaan program, implementasi program dan project assurance. Sementara itu, mekanisme bantuan ekonomi memfasiltasi Indonesia untuk menerima bentuk bantuan pembiayaan yang akan mendukung implementasi Program HPMP di Indonesia. Dalam mekanisme bantuan ekonomi program, UNDP sebagai lembaga pelaksana utama berperan sebagai lembaga yang mendistribusikan bantuan ekonomi dan sumber donor pembiayaan terbesar.

Implementasi Program HPMP di Indonesia yang diterapkan oleh UNDP sebagai lembaga pelaksana utama menunjukkan peran UNDP sebagai sumber norma dan legitimasi yang kemudian diinternalisasi dan berdampak pada perilaku negara. Fungsi UNDP sebagai penyebar norma di Indonesia untuk melindungi lapisan ozon dengan mengontrol persebaran Bahan Perusak Ozon (BPO) pada tahap awal dapat direfleksikan dalam terbentuknya lemaga-lembaga nasional yang menjadi institusiinstitusi nasional yang bertanggung jawab untuk implementasi Program HPMP di Indonesia. Selanjutnya, pengadopsian pendekatan bottom-up menciptakan berbagai persuasi dan tekanan politik dari sektor privat. Rangkaian proses dalam program kemudian menghasilkan perubahan sudut pandang dari semua pemangku kebijakan yang terlibat untuk seluruhnya menginternalisasi standar normatif internasional yang menjadi agenda UNDP dalam Program HPMP. Perubahan sudut pandang tersebut ditandai dengan adanya regulasi nasional terkait pembatasan konsumsi BPO dan Perlidungan Lapisan Ozon (PLO). UNDP melalui Program HPMP yang berhasil mendorong internalisasi norma internasional di Indonesia yang ditandai dengan ditetapkannya regulasi nasional menunjukkan bahwa semua institusi telah siap untuk bersama-sama menjalankan regulasi nasional yaitu Peraturan Menteri Perindustrian Nomor: 41/M-Ind/ Per/5/2014 tentang Larangan Penggunaan HCFC di Bidang Perindustrian dan Peraturan Menteri Perdagangan Nomor: 55/M-Dag/Per/9/2014 tentang Impor Barang Berbasis Pendingin yang keduanya merupakan bentuk internalisasi norma internasional. 


\section{Daftar Pustaka}

Alderson, K. (2001). Making Sense of State Socialization. Review of International Studies, 27(3), pp. 415-433.

Barnett, N. \& Finnemore, M. (1999). The Politics, Power, and Pathologies of International Organizations. International Organization, 53(4), pp. 699-732.

Brockhaus, M. et al. (2012). An overview of Forest and Land Allocation Policies in Indonesia: Is the Current Framework Sufficient to Meet the Needs of REDD+?. Forest Policy and Economics, 18 May, pp. 30-37.

Filkin, K., et al. (2010) National Survey and Development of a National Strategy Outline of HCFC Phase-Out for Consumption Sectors in Republic of Bulgaria [Online]. Tersedia dalam: <https://www. researchgate.net/publication/282328045_National_Survey_and_ Development_of_a_National_Strategy_Outline_of_HCFC_Phase Out_for_Consumption_Sectors_in_Republic_of_Bulgaria> [Diakses 14 Oktober 2019].

Glover, A., \& Schroeder, H. (2016). Legitimacy in REDD+ Governance in Indonesia. International Environmental Agreements: Politics, Law, and Economics, 17(5), pp. 695-708.

KLHK (2014) Regulasi Program Penghapusan Bahan Perusak Ozon "HCFC" di Indonesia [Online], Kementerian Lingkungan Hidup dan Kehutanan. Tersedia dalam: <http://www.menlh.go.id/regulasiprogram-penghapusan-bahan-perusak-ozon-hcfc-di-indonesia/> [Diakses 15 Oktober 2019].

Koh, H. H. (1997). Why Do Nations Obey International Law? Yale Law Journal, 106(8), pp. 2599-2659.

Luttrell, C., et al. (2014). The Political Context of REDD+ in Indonesia: Constituencies for Change. Environmental Science $\mathcal{E}$ Policy, 35, pp. 67-75.

Purnomo, H., Luki, A., \& Suyamto, D. (2012). REDD+ Actor Analysis and Political Mapping: An Indonesia Case Study. International Forestry Review, 14(1), pp. 74-89.

Sulistiawati, L. Y. (2014). REDD+ Issues Influence in Indonesia's Regulatory Process. Disertasi Ph.D, University of Washington.

UNEP (n.d.) About Montreal Protocol [Online], United Nations Environment Programme. Tersedia dalam: <https://www.unenvironment.org/ ozonaction/who-we-are/about-montreal-protocol> [Diakses 25 Oktober 2019].

UNDP (n.d.a) Sustainable Development Goals [Online], United Nations Development Programme. Tersedia dalam: <http://www.undp. org/content/undp/en/home/sustainable-development-goals.html> [Diakses 18 Oktober 2019]. 
UNDP (2017) Assessment Reports of Emissions Of Hydrofluorocarbons (HFC) [Online], United Nations Development Programme. Tersedia dalam: <https://www.undp.org/content/undp/en/home/librarypage/ environment-energy/ozone_and_climate/assessments-of-hfcemissions.html> [Diakses 17 Oktober 2019].

UNEP(2013) Executive Committee of The Multilateral Fund for The Implementation of The Montreal Protocol Seventy-first Meeting (No. UNEP/OzL.Pro/ ExCom/71/64/Corr.1) [Online], United Nations Environmental Programme. Tersedia dalam: <http://www.multilateralfund.org/71/ English/1/7164_and_c1.pdf > [Diakses 17 Oktober 2019].

UNEP(2011) Executive Committee of The Multilateral Fund for The Implementation of The Montreal Protocol Sixty-fourth Meeting (No. UNEP/OzL. Pro/ExCom/64/34) [Online], United Nations Environmental Programme. Tersedia dalam: <http://www.multilateralfund.org/ MeetingsandDocuments/currentmeeting/64/English/1/6434.pdf> [Diakses 17 Oktober 2019].

IMF (2015) Executive Committee of The Multilateral Fund for The Implementation of The Montreal Protocol Seventy-fifth Meeting (No. UNEP/OzL.Pro/ExCom/75/49) [Online], United Nations Environmental Programme. Tersedia dalam: <http://www. multilateralfund.org/75/English/1/7549.pdf> [Diakses 17 Oktober 2019].

UNFPA (2015) Transforming our world: The 2030 Agenda for Sustainable Development [Online], United Nations Populations Fund. Tersedia dalam: <https://www.unfpa.org/resources/transforming-our-world2030-agenda-sustainable-development> [Diakses pada 18 Oktober 2019].1996). 